NBER WORKING PAPER SERIES

\title{
SUDDEN STOP, FINANCIAL FACTORS AND ECONOMIC COLLAPSE IN LATIN AMERICA: LEARNING FROM ARGENTINA AND CHILE
}

\author{
Guillermo A. Calvo \\ Ernesto Talvi \\ Working Paper 11153 \\ http://www.nber.org/papers/w11153
NATIONAL BUREAU OF ECONOMIC RESEARCH 1050 Massachusetts Avenue
Cambridge, MA 02138
February 2005

This paper was prepared for the debate "From the Washington Consensus Towards a New Global Governance" held at the Forum Barcelona, in Barcelona, Spain, September 24-26, 2004. We would like to thank very especially Diego Pereira and the rest of CERES's research assistants Ignacio Munyo, Virginia Olivella and Inés Levin for their excellent work and John Dunn Smith for superb editorial support. We would like to acknowledge the insightful comments by Sara Calvo on a previous version. The views expressed herein are those of the author(s) and do not necessarily reflect the views of the National Bureau of Economic Research.

(C) 2005 by Guillermo A. Calvo and Ernesto Talvi. All rights reserved. Short sections of text, not to exceed two paragraphs, may be quoted without explicit permission provided that full credit, including $\odot$ notice, is given to the source. 
Sudden Stop, Financial Factors and Economic Collapse in Latin America: Learning from Argentina and Chile

Guillermo A. Calvo and Ernesto Talvi

NBER Working Paper No. 11153

February 2005

JEL No. F31, F32, F34, F41

\section{ABSTRACT}

This paper shows that the Russian 1998 crisis had a big impact on capital flows to Emerging Market Economies, EMs, especially in Latin America, and that the impact of the Russian shock differs quite markedly across EMs. To illustrate this statement, we compare the polar cases of Chile and Argentina. While Chile exhibited a significant economic slowdown after August 1998, it did not suffer the excruciating collapse suffered by Argentina, where even the payments system came to a full stop. We attribute their difference to the fact that Chile is more open to trade than Argentina, and that it appears to suffer much less from balance-sheet currency-denomination mismatch that was rampant in Argentina before the 2002 crisis (due to large domestic liability dollarization). The paper is essentially descriptive but is in line with and, thus, complements econometric studies like Calvo, Izquierdo and Mejia (NBER Working Paper 10520). The final section addresses policy issues in light of the paper's findings and conjectures.

Guillermo A. Calvo

Inter-American Development Bank

Stop B-600

1300 New York Ave., NW

Washington, DC 20577

and NBERgcalvo@iadb.org

Ernesto Talvi

CERES

Antonio Costa 3476

11300 Montevideo

Uruguay

etalvi@ceres-uy.org 
Latin America does not grow. It occasionally hits an ice patch where output speeds up, only to fall on its face when the ice patch ends. Moreover, in the glorious 1960s when the region was hurtling along at high speed, it was outpaced by other regions, including the OECD. Thus, in contrast to advanced economies (the North), in which the business cycle has given way to growth as the main subject of professional attention, in Latin America business fluctuations remain the name of the game. Reducing volatility and avoiding the exhilaration of the ice patch have become primary policy commandments.

Unfortunately, false starts and painful crashes have not given rise to a solid academic literature comparable to the one dealing with problems in the North. Rather, the failure of a false start is quickly attributed to the skates used on the ice patch. Thus, after the crash policymakers go quickly to the store to buy a new pair of skates instead of learning how to skate on an ice patch that is less than totally smooth. Instead of analysis and ideas, new slogans are printed on political banners declaring "the model has failed," "the model is exhausted." or other empty statements of that nature. When the Debt Crisis erupted in the early 1980s, politicians, cheered by international multilateral institutions, declared the failure of Import Substitution and bought a brand new pair of Washington Consensus skates. Few stopped to think that the 1982 crisis in Latin America had systemic elements and followed a sharp increase in US interest rates that precipitated a collapse of capital flows to the region. ${ }^{1}$ After the 1998 Russian crisis, which set off a string of Emerging Market (EM) financial crises, politicians started to sneak out of their Washington Consensus skates and again went shopping for a new pair. It is still too early to know what will be the new fashion, but some very prestigious ice skate producers are forcefully vying for attention!

Intellectual fickleness, however, militates against credibility, and without credibility policy is likely to be ineffective, if not counterproductive. ${ }^{2}$ Thus, we strongly believe that a deeper understanding of financial crises in the region constitutes one of the most productive projects. We said "productive," not "easy," because typically the observer is limited by a very small number of observations relative to the shocks and regime changes during the observation period.

This paper will focus on the last gasps of the Washington Consensus, which began to be heard in the aftermath of the 1998 Russian crisis. In contrast to much

\footnotetext{
${ }^{1}$ However, see Calvo and Borensztein (1989).

${ }^{2}$ See for example, Calvo (1989).
} 
current thinking, we do not fault the Washington Consensus for what it says. Rather, we fault it for what it does not say, particularly for ignoring several key financial factors. Thus, for example, the Washington Consensus ignored the key role of high volatility of international capital markets. The Washington Consensus also ignored central characteristics of domestic capital markets in Latin America and other EMs such as the high incidence of foreign currency debt (Liability Dollarization).

We will argue that poor growth performance-and the new crop of crises in Latin America in the late 1990s and the early years of the new millennium-were largely the result of the Russian crisis, which brought about an unprecedented, acrossthe-board increase in interest rates for EMs and a systemic collapse of capital flows to the region. This is vividly suggested by Figure 1. Nevertheless, the implications of the Russian crisis for Latin America are still badly understood, and they have given rise to the erroneous notion that Reforms do not work.

Figure 1. LAC-7 External Financial Flows and Economic Growth*

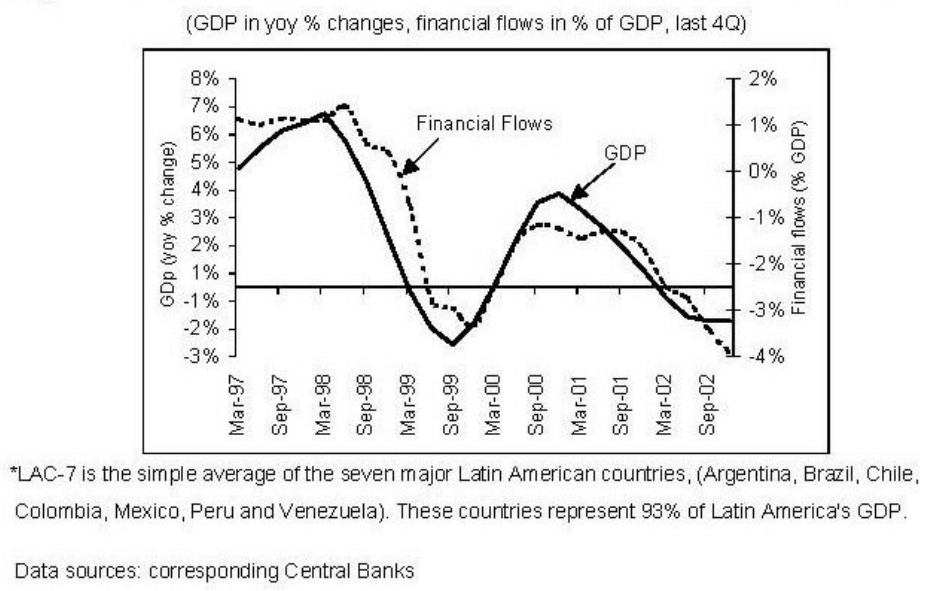

Furthermore, we will argue that the systemic collapse in capital flows, when combined with domestic financial vulnerabilities that acted as amplifiers of the external shock, also goes a long way towards explaining how individual countries in Latin America fared during the late 1990s: who was badly hit (Argentina), experiencing a major financial crisis and economic collapse with severe social consequences, and who suffered painful macroeconomic adjustments (Chile) but emerged largely unscathed.

This alternative interpretation of the disappointing performance and recent crop of crises in Latin America in the late 1990s has very important policy implications. 
Once one takes into account financial factors, most of the pieces of the puzzle fall into place. Thus, these crises imply no momentous break from the conventional wisdom prevailing in the 1990s, as doomsayers would have us believe. Rather than throwing overboard the reform efforts of the 1990s, EMs should focus on identifying and fixing key "points of financial vulnerability" and reinforcing policy credibility. In turn, the focus of attention of the international community should be redirected to fixing the international financial architecture in ways that resources, financial and otherwise, can be mobilized in a more efficient and stable manner from central to peripheral countries. This topic is highly relevant because there are incipient signs of resumption in capital flows to emerging market economies. Thus, it is extremely important to contain the seeds of future crises before they have time to germinate.

The next section documents the boom and bust, i.e., the systemic, large and largely unexpected interruption in external capital flows to Latin America (i.e., a Sudden Stop) following the Russian crisis. As this Sudden Stop affected a very large number of heterogeneous countries in very different regions of the world at about the same time, it is very difficult to construe this Sudden Stop as the result of a coordinated reassessment of the economic fundamentals of individual countries or regions. Rather, we argue that the root cause of the Sudden Stop lies in developments in the central financial markets. Section II describes the anatomy of Latin America's painful macroeconomic adjustment and sharp reduction in growth rates following the Sudden Stop in capital flows. Special attention is paid to the case of Chile, as Chile suffered a severe Sudden Stop in capital flows and a painful macroeconomic adjustment in the aftermath of the Russian crisis, in spite of its very solid economic fundamentals and tight controls on capital inflows. However hard the landing and painful the adjustment, the Chilean economy experienced no financial crisis and did not collapse as did Argentina's economy. In Section III we use the comparative experiences of Chile and Argentina after the Sudden Stop in capital flows in the aftermath of the Russian crisis, to address the key domestic financial vulnerabilities that acted as amplifiers of the initial external financial shock, transforming an otherwise painful macroeconomic adjustment into a full-blown financial crisis and economic collapse. Section IV concludes with some reflections on policy. 


\section{Life after Russia, or the Chronicle of a Sudden Stop}

The 1990s was a decade of formidable economic expansion of the US economy. The revolution in information and communications technology produced an investment boom, and investment in the US rose at an average rate of 6.7 percent between 1991 and 2000 , compared to 3.7 percent in the previous decade. This investment was stimulated by both the emergence of new firms and the incorporation of new technologies into existing firms. As a result, the US economy saw formidable advances in productivity that led to a boom in stock market values: the Dow Jones multiplied by four and one half and the NASDAQ by fourteen between October 1990 and early 2000. This huge increment in financial wealth also precipitated an equally large increment in the financial resources available for firms and households.

Emerging economies were direct beneficiaries of this enormous increase in investment and financial resources. Starting in 1989-90 there was a huge increase in capital flows to emerging economies, in the form of both direct investment and financing. According to IMF figures, net capital flows went from 29 billion dollars in 1989 to 227 billion dollars in 1996, when they reached their peak, an eightfold increment in a very short period of time. This huge wave of capital inflows to EMs in the first half of the 1990s makes the previous wave of inflows that occurred between mid-1970s and the early 1980s pale by comparison. We believe that the year 1989 could justifiably be considered the beginning of financial globalization in the modern era.

By the end of the 1980s, with the implementation of the Brady Plan, Latin American countries were on the verge of finally resolving the 1980s debt crisis and hence renewing their access to international capital markets. As a result, Latin America also benefited from the huge wave of capital inflows that started in the early 1990s. As illustrated in Figure 2, external capital flows to the major Latin American countries (henceforth LAC-7), which all but vanished after the debt crisis of the early 1980s, jumped from minus 13 billion dollars (or minus 1.1 percent of GDP) by the year ending in IV-1989 to 100 billion dollars (or 5.5 percent of GDP) in the year ending in II-1998. ${ }^{3}$

\footnotetext{
3 LAC-7 includes the seven major Latin American economies, namely, Argentina, Brazil, Chile, Colombia, Mexico, Peru, and Venezuela. These countries represent 93 percent of Latin America's GDP.
} 
At their peak, external capital flows to LAC-7 were financing 24 percent of total investment in the region.

Figure 2. Boom and Bust in Capital Flows to LAC-7. 1990-2002*

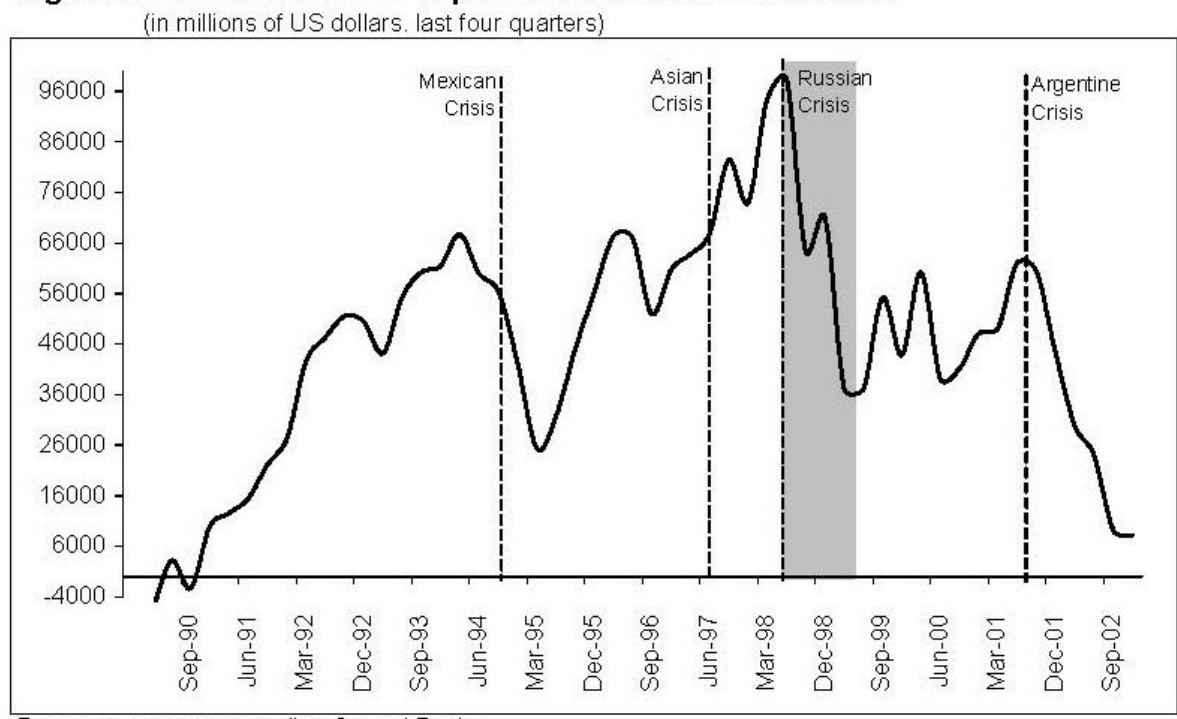

Data sources: corresponding Central Banks

Table 1. Boom and Bust in Capital Flows per Country

\begin{tabular}{lccc}
\multicolumn{2}{c}{ (in \% of GDP. last four quarters) } & \multicolumn{3}{c}{ Boom } & \multicolumn{2}{c}{ Bust } \\
\cline { 2 - 4 } Country & $\begin{array}{c}\text { Avg 1985-1990 } \\
\text { vs } \\
\text { peak 1998 }\end{array}$ & $\begin{array}{c}\text { peak 1998 } \\
\text { vs } \\
\text { trough 1999 }\end{array}$ & $\begin{array}{c}\text { peak 1998 } \\
\text { vs } \\
2002\end{array}$ \\
\hline Chile & & & \\
Peru & 9.3 & -7.9 & -5.2 \\
Colombia & 16.0 & -7.2 & -4.7 \\
Brazil & 2.1 & -6.6 & -3.5 \\
Venezuela & 8.5 & -5.8 & -3.8 \\
Argentina & 5.4 & -3.5 & -17.4 \\
Mexico & 8.5 & -2.2 & -19.5 \\
Average & 3.8 & -1.9 & -1.7 \\
& & & -8.0 \\
\hline
\end{tabular}

Data sources: corresponding Central Banks

"LAC-7 includes the seven major Latin American countries. namely. Argentina. Brazil. Chile. Colombia Mexico. Peru and Venezuela. These countries represent $93 \%$ of Latin America's GDP. 
This new wave of capital inflows was not only large, but also widespread, as illustrated in Table 1. Cheap and abundant capital and financing were pouring into every country in the region. At their peak in mid-1998, net capital flows to LAC-7 had increased by close to 7 percentage points of GDP relative to 1989, and the swing was positive and significant in every country. This highly synchronized and widespread increase in capital inflows to a variety of very diverse countries suggests that the root cause of this bonanza must lie in common external factors, i.e., developments in central rather than in peripheral countries. ${ }^{4}$ However, external does not necessarily mean that capital inflows are independent of domestic fundamentals. This important and subtle difference is precisely the topic of Section III.

A key feature of the 1990s was that non-FDI financial flows to Latin America were in the form of portfolio flows, while other emerging markets, such as the emerging Asian countries, were mainly recipients of bank loans. Calvo (2002) suggests that a relevant factor could have been the creation of a secondary market for sovereign bonds in Latin America as a result of the Brady Plan, which transformed bank loans into bonds. The Brady debt reduction plan, which mostly focused on Latin America, created for the first time a critical mass of long-term bonds that needed to be managed and traded by specialists. The creation of this market allowed fund managers of risky portfolios to include Latin American risk and made it worthwhile to invest in information on Latin American economies; expanding investors' interest in the region as their knowledge of the region grew.

Mexico's Tequila crisis in 1994-95 produced only a temporary reversal in capital flows to Latin America, and its effects were limited in scope, mainly affecting Argentina (see Figure 2). However, a key lesson learned from the Mexican experience was that countries were financially more fragile than previously thought: even if their long-term capacity to pay was sufficient to cover obligations, they could be rendered insolvent if a critical mass of investors refused to roll over short-term bonds (Mexico) or bank deposits (Argentina). In such a situation, investors could rationally refuse to lend, and a crisis would ensue. ${ }^{5}$

\footnotetext{
${ }^{4}$ The role of external factors in explaining inflows and outflows of capital and economic performance in emerging economies has been emphasized in Calvo, Leiderman and Reinhart (1993).

${ }^{5}$ See Calvo (1998).
} 
The second crisis episode was the Asian crisis of 1997. This crisis hit countries with very high saving rates and an impeccable record of high growth. ${ }^{6}$ It became apparent that liquidity crises were also a possibility not only in the case of bonded debt, but also in the case of bank lending, whether intermediated through the domestic banking system or directly allocated to local firms. However, not even the Asian crisis interrupted the exponential increase in capital flows to Latin America. Rather, the Asian crisis hit Latin America through trade channels by depressing commodity prices: nonfuel commodity prices fell by nearly 30 percent from their peak in II-1997 to their trough in early 2002. This decline in commodity prices contributed in some specific cases, notably Chile and Peru, to a deceleration in growth rates.

It was Russia's default in August 1998, however, that represented a fatal blow for Latin America. This default precipitated a sudden, synchronized, large and persistent increase in interest rates for EMs. In tandem with the rest of emerging markets, interest rate spreads for LAC-7 rose from 450 basis points prior to the Russian crisis to 1,600 basis points in September 1998, more than tripling the cost of external financing in a period of weeks. As a result, capital inflows to LAC-7 countries came to a Sudden Stop, falling from 100 billion dollars (or 5.5 percent of GPD) in the year ending in II-1998 prior to the Russian crisis, to 37 billion dollars (or 1.9 percent of GDP) one year later (see Figure 2). The sudden reversal is explained by the collapse in non-FDI flows, which fell by 80 billion dollars during that period.

After the initial blow, capital flows to LAC-7 suffered an additional blow after the Argentine crisis in 2001 (which, as we will argue, was triggered by Russia's crisis) and, later, the ENRON scandal that had a major-albeit temporary-effect on both US junk bonds and emerging markets. ${ }^{7}$ By the year ending in IV-2002 capital flows to LAC-7 were less than 10 billion dollars, back to the very low levels of the late 1980s.

The Russian virus affected every major country in Latin America, with the exception of Mexico (see Table 1). Even Chile, a country with very solid economic fundamentals - a track record of sound macroeconomic management, a highly praised and sustained process of structural and institutional reforms that completely transformed and modernized Chile's economy, and an average rate of growth of 7.4 percent per year

\footnotetext{
${ }^{6}$ In the aftermath of the devaluation of the Thai currency in July 1997, capital flows to emerging Asian countries, i.e., Indonesia, Korea, Malaysia, Philippines and Thailand, fell from 47 billion dollars (or 4.3 percent of GDP) in the year ending II-97, to minus 58 billion dollars (or -5.5 percent of GDP) one year later.

${ }^{7}$ For a brief analysis of the relationship between the ENRON scandal and emerging market bond spreads see Calvo and Talvi (2002).
} 
between 1985 and 1997, the highest growth rate in LAC-7-and tight controls on the inflows of foreign capital, experienced a sudden and severe interruption in capital inflows. In fact, the Sudden Stop in Chile in the year following the Russian crisis was 7.9 percent of GDP, the largest in LAC-7.

That a partial debt default in Russia, a country that represented less than 1 percent of world GDP and had no meaningful financial or trading ties with Latin America, could precipitate a financial contagion shock wave of such proportions, posed a puzzle for the profession. In our view, the kind of explanation that is consistent with the evidence, i.e., a sudden, synchronized and widespread increase in interest rates for EMs, is that financial contagion was caused by the impact of Russia's crisis on the balance sheet of financial intermediaries investing in emerging markets. These intermediaries were highly leveraged, and the accumulation of losses after Russia's default led to a liquidity crunch, forcing a sell-off of EM bonds across the board at fire sale prices to meet margin calls. ${ }^{8}$ In fact, during the Russian crisis big players in the central capital markets were subject to a liquidity crunch, prompting the Fed and the ECB to lower interest rates as a result. Unfortunately, however, liquidity relief came only when the crisis threatened the stability of US and European markets-too late to restore confidence in EMs.

An alternative systemic explanation for the widespread effect of the Russian crisis is Reverse Moral Hazard. According to this explanation, the IMF refusal to bail out Russia sent a strong signal to the market that the IMF would no longer support blanket bailouts. This, in turn, increased the perceived risk of investing in EMs and orchestrated a run on EM securities. Reverse Moral Hazard is complementary to the one relying on liquidity crunch in the central capital market and, furthermore, reinforces the view that EMs were badly hit by the Russian crisis. Although this is not the place to engage on a debate about the relevance of the Reverse Moral Hazard view, we believe that this view is highly debatable, given that the IMF has since arranged generous packages for Brazil and Turkey. ${ }^{9}$

To be fair, there is another possible interpretation for the reversal in capital flows in the 1990s, and this view lays the blame on domestic reform. Some critics of the reforms of the early 1990s, such as Stiglitz (2003), argue that the global financial crisis

\footnotetext{
${ }^{8}$ For a theoretical explanation of this kind of contagion see Calvo (1999a) and Calvo and Mendoza (2000). For empirical evidence supporting this class of explanations see Kaminsky and Reinhart (2001 and 2003).

${ }^{9}$ See Calvo (2002).
} 
was itself the product of capital market liberalization, which was an integral part of the reform agenda of the 1990s. Although one could argue that the opening of the capital account could have facilitated destabilizing capital flows (i.e., "hot money"), this does not explain the synchronized nature of the reversal in capital flows that occurred in Latin America in 1998. Moreover, those who find fault with an open capital account will be hard-pressed to explain why capital flow reversal also took place in countries that had imposed controls on capital inflows, like Chile.

In summary, the deterioration in international financial conditions for emerging economies and the consequent interruption in capital flows to a variety of very heterogeneous countries - in terms of exchange rate regimes, capital controls, fiscal stance, track record of structural and institutional reforms and growth performancewas so sudden, synchronized and widespread that it appears implausible to argue it was caused by a sudden and coordinated reassessment of the economic fundamentals of individual countries in the region. ${ }^{10}$ Rather, a more straightforward explanation is that the dramatic increase in interest rates for Latin American economies and the ensuing interruption in capital flows was the result of a disruption in international financial markets in the aftermath of Russia's default.

\section{Sudden Stops and Macroeconomic Adjustment in Latin America}

The Sudden Stop in capital flows precipitated a very severe and painful macroeconomic adjustment and a sharp reduction in economic growth in Latin America. ${ }^{11}$ The anatomy of this adjustment in LAC-7 is illustrated in Figure 3. The following are its main characteristics.

\footnotetext{
${ }^{10}$ The diversity in the degree of advancement of structural reforms has been extensively documented in Lora (2001).

${ }^{11}$ This represents a "hard landing," to use the term that, paradoxically, currently is associated with concerns regarding the size of the external current account deficit of the US economy (5 percent of GDP) and fears that a change in market sentiment (a Sudden Stop?) might force a major macroeconomic adjustment in the US.
} 
Figure 3. Sudden Stop and Macroeconomic Adjustment in LAC-7, 1990 - 2002 *

3a. Global Bonds Spread

(EMBI+ adjusted for Argentina, in bp)

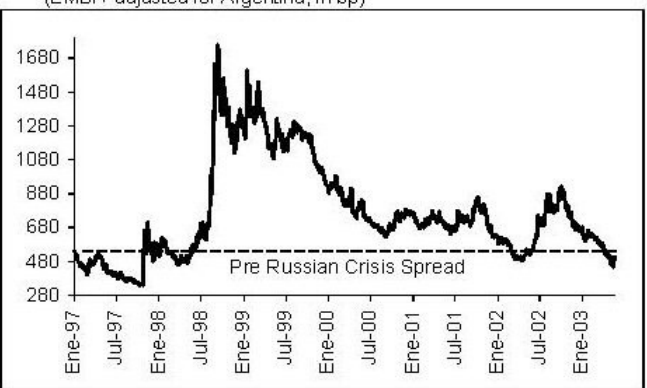

3c. External Financial Flows

(non-FDI flows +E\&O, in billions of 2003 US dollars)

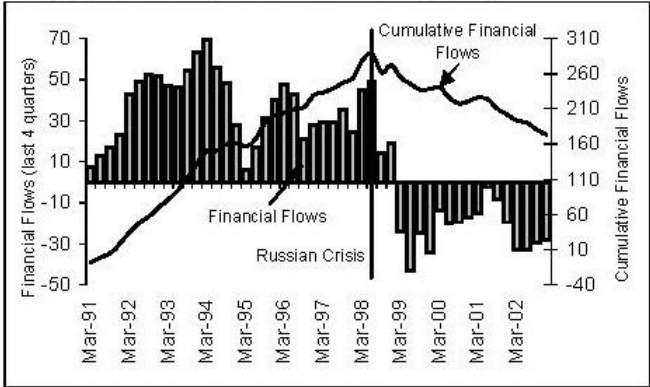

3e. Current Account

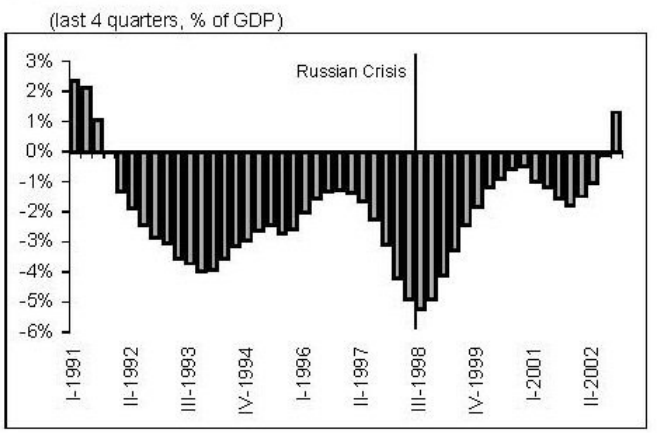

3g. Investment, 1990-2002

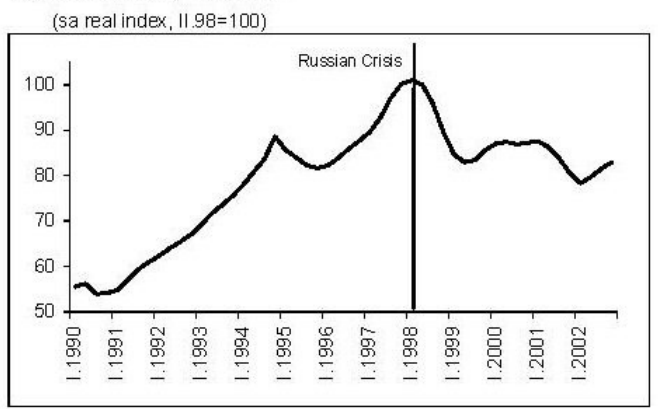

3b. Stock Prices

(local stock indices in US dollars, Jul 97=100)

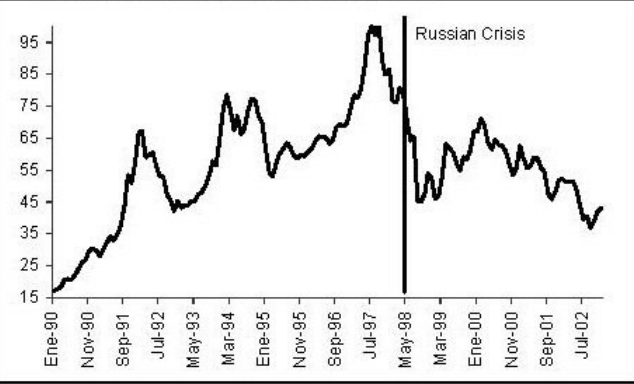

3d. Domestic Bank Credit Stocks and Flows

(to the private sector, deflated by CPI, Jun $98=100$ )

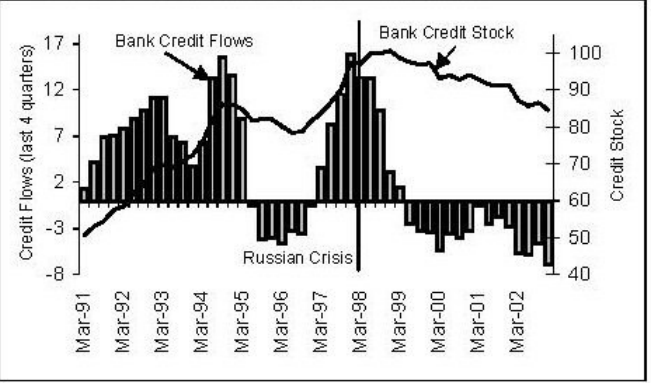

3f. Real Exchange Rate

(vis-à-vis the US dollar, June $98=100$ )

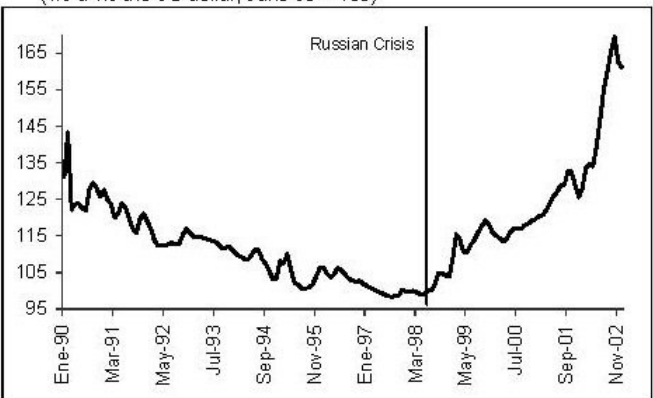

3h. Economic Activity, 1990-2002

(GDP, sa real index $11.1998=100$ and annualized qoq growth rate)

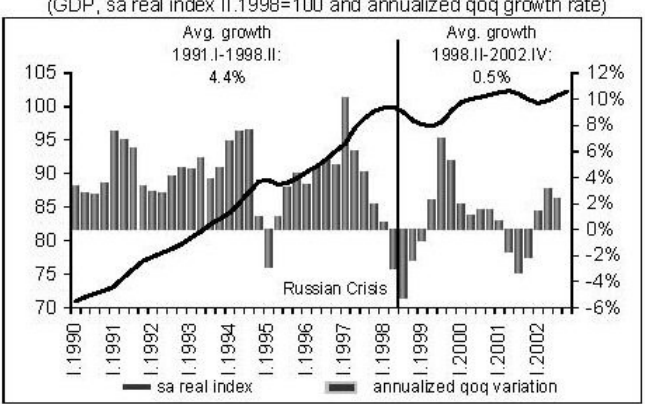

Data sources: corresponding Central Banks

"LAC-7 is the simple average of the seven major Latin American countries, namely, Argentina, Brazil, Chile, Colombia,

Mexico, Peru and Venezuela. These countries represent $93 \%$ of Latin America's GDP. 
1. A very large and persistent increase in the cost of external financing and a collapse in asset prices

The increase in interest rate spreads and the cost of external financing for LAC-7 was not only large — spreads tripled in a matter of weeks—but also persistent: it took nearly five years for spreads to return to the levels prevailing prior to the Russian crisis (see Figure 3a).

Such a severe tightening in monetary and credit conditions in such a short period of time has no parallel in developed countries. It should come as no surprise that it resulted in a severe drop in asset prices. LAC-7 stock markets, which had already started to decline after the Asian crisis, collapsed by an additional 48 percent from their relative peak in II-1998 to their trough in IV-2002, after experiencing a ten-fold increase between 1991 and 1997 (see Figure 3b).

2. A Sudden Stop in external financial flows and domestic bank credit and sharp financial deleveraging

The dramatic tightening in monetary and credit conditions, both external and internal, and the reduction in the value of collateral, signaled that current debt levels were unsustainable. The result was a Sudden Stop in external financial flows and domestic bank credit flows which did not merely decline but in fact turned negative. As a result, the Sudden Stop was accompanied by a very sharp and persistent financial deleveraging on the part of LAC-7 households and firms.

External financial flows (i.e., non-FDI capital flows) experienced a dramatic turnaround in the immediate aftermath of the Russian crisis, falling from 40 billion dollars in the year to II-1998 to minus 40 billion one year later, and they have remained persistently negative since then. This means LAC-7 countries have been transferring net financial resources abroad, in sharp contrast with the period preceding the Russian crisis. As a result, external financial flows fell from a cumulative total of 200 billion (real) dollars between I-1990 and II-1998 and to a cumulative total of 120 billion (real) dollars by the IV-2002, a reduction of 40 percent (see Figure $3 \mathrm{c}$ ). ${ }^{12}$

12 Real dollars are 2003 dollars, using the US CPI as a deflator. 
Domestic bank credit flows to the private sector also came to a Sudden Stop and actually turned persistently negative (see Figure $3 \mathrm{~d}$ ). As a result, financial deleveraging also took place at the domestic level in LAC-7: domestic bank credit to the private sector declined by 20 percent in real terms (see Figure $3 \mathrm{~d}$ ). It took a very protracted period of financial deleveraging and a substantial improvement in international financial conditions (i.e., a large reduction in US interest rates) for interest rate spreads of emerging economies and the cost of external financing to return to pre-Russian levels in early 2003. However, capital flows to LAC-7 recovered only slightly in 2003 and 2004 and still remain substantially below their previous heights.

To understand this apparent puzzle it is important to stress the nature of the shock and the corresponding adjustment. Borrowing in international markets can smooth an adverse shock to current income, such as a fall in the terms of trade. Such a shock would be associated with a deteriorating current account and an increase in inflows of foreign capital. However, the type of shock experienced by the Latin American economies in the aftermath of the Russian crisis is not an adverse income shock but an adverse shock to the capital account, i.e., a shock to the cost and availability of capital and credit. This type of shock is by definition undesirable if not impossible to smooth. On the contrary, it induces a major adjustment in the stocks of debt, which under the new and tighter conditions are too "expensive" to sustain. It is precisely this adjustment in debt stocks or deleveraging on the part of firms and households that allows for an endogenous reduction in the cost of external financing. However, the endogenous reduction in the cost of external financing can only be sustained by lower stocks of debt and, in turn, lower capital inflows.

The Sudden Stop in capital flows and external financial deleveraging (or the transfer of net financial resources abroad) had its counterpart in a sharp current account adjustment and real currency depreciation. The current account of LAC-7 went from a deficit of 5 percent of GDP in the year ending in II-1998 to a surplus of 1.3 percent of GDP in the year ending in IV-2002, an adjustment equivalent to 6.3 percentage points of GDP (see Figure 3e). During the same period, the real value of domestic currencies in LAC-7 vis-à-vis the US dollar depreciated by 70 percent (see Figure 3f). As illustrated in Table 2 the adjustment in the current account and currency values was highly synchronized: every country in LAC-7-with the notable exception of Mexicoexperienced large current account adjustments and currency depreciation during this period. 
Table 2. Current Account Reversals and the Real Exchange Rate (RER) per Country

\begin{tabular}{|c|c|c|c|c|}
\hline \multirow[b]{3}{*}{ Country } & \multicolumn{3}{|c|}{$\begin{array}{c}\text { Current Account } \\
\text { in \% of GDP, 1998-2002 }\end{array}$} & \multirow{3}{*}{$\begin{array}{l}\text { RER Depreciation } \\
\text { Jun } 98 \text { vs Dec } 02\end{array}$} \\
\hline & \multicolumn{2}{|c|}{ Year to } & \multirow[b]{2}{*}{ Reversal } & \\
\hline & $11-1998$ & IV-2002 & & \\
\hline Argentina & -4.7 & 8.9 & 13.6 & 185.3 \\
\hline Venezuela & -2.5 & 9.2 & 11.7 & 20.3 \\
\hline Chile & -6.5 & -1.3 & 5.2 & 47.5 \\
\hline Peru & -7.0 & -2.0 & 5.0 & 22.4 \\
\hline Colombia & -6.5 & -1.8 & 4.7 & 61.2 \\
\hline Brazil ${ }^{*}$ & -3.9 & -1.7 & 4.2 & 151.0 \\
\hline Mexico & -3.0 & -2.2 & 0.8 & -13.9 \\
\hline Average & -4.9 & 1.3 & 6.5 & 67.7 \\
\hline
\end{tabular}

3. Severe and sustained contraction of investment and a sharp reduction in economic growth

The other side of the coin of financial deleveraging and the large current account adjustment was a severe and sustained reduction in investment levels. To see this, let us consider how the stocks of debt in the balance sheets of households and firms can be reduced. There are essentially three ways. First, for any given level of investment, households and firms must forego consumption in order to increase savings and hence, increase the resources available to reduce debt levels. Alternatively, for any given level of savings, households and firms must reduce investment in order to use part of their savings to reduce debt levels. Finally, debt levels can be reduced through negotiated debt restructuring with creditors.

Although in practice the three modes of balance-sheet adjustment are typically observed, the reduction in investment in LAC-7 has played a major role in the adjustment to tighter international financial conditions. Investment declined by 18 percent in the immediate aftermath of the Russian crisis, and by the fourth quarter of 2002 still showed no signs of recovery (see Figure 3g). Investment growth rates collapsed from an average of 9 percent per year between 1991 and 1997 to minus 5 percent per year between 1999 and 2002, and investment ratios fell from 23 percent of 
GDP in 1997, prior to the Russian crisis, to 18 percent of GDP in 2002, a reduction of 5 percentage points. In fact, it was the reduction in investment ratios, rather than an increase in saving rates, that made the largest contribution to the current account adjustment.

As was the case with the slowdown of capital flows, the collapse in the growth rates of investment and investment ratios was also synchronized and widespread and affected every single country in the region (see Table 3). In fact, with the sole exception of Mexico, average investment growth was negative between 1999 and 2002 in every LAC-7 country.

Table 3. Growth and Investment Reversals

\begin{tabular}{|c|c|c|c|c|c|c|c|c|c|c|}
\hline \multirow[b]{2}{*}{ Country } & \multicolumn{3}{|c|}{$\begin{array}{c}\text { GDP } \\
\text { (avg annual \% change) }\end{array}$} & \multicolumn{3}{|c|}{$\begin{array}{c}\text { Investment } \\
\text { (avg annual } \% \text { change) }\end{array}$} & \multicolumn{4}{|c|}{$\begin{array}{c}\text { Investment Ratio } \\
(\% \text { GDP })\end{array}$} \\
\hline & $1991-1997$ & 1999-2002 & Reversal & $1991-1997$ & 1999-2002 & Reversal & 1991 & 1997 & 2002 & Reversal \\
\hline Argentina & 6.1 & -4.9 & -10.9 & 14.8 & -17.9 & -32.7 & 14.6 & 19.4 & 13.9 & -5.5 \\
\hline Chile & 8.3 & 2.2 & -6.2 & 13.7 & -5.0 & -18.8 & 22.6 & 27.2 & 21.1 & -6.1 \\
\hline Venezuela & 3.4 & -2.2 & -5.6 & 18.5 & -4.8 & -23.4 & 18.7 & 21.0 & 14.3 & -6.7 \\
\hline Colombia & 4.0 & 0.4 & -3.5 & 9.3 & -2.2 & -11.5 & 15.9 & 22.0 & 15.1 & -6.9 \\
\hline Peru & 5.3 & 2.5 & -2.8 & 11.5 & -6.5 & -18.0 & 17.3 & 24.0 & 18.4 & -5.6 \\
\hline Brazil & 3.1 & 2.0 & -1.1 & 4.3 & 0.1 & -4.2 & 19.8 & 21.5 & 18.1 & -3.4 \\
\hline Mexico & 2.8 & 2.7 & -0.1 & 6.9 & 1.6 & -5.3 & 23.3 & 25.9 & 24.1 & -1.8 \\
\hline Average & 4.7 & 0.4 & -4.3 & 11.3 & -5.0 & -16.3 & 18.9 & 23.0 & 17.9 & -5.1 \\
\hline
\end{tabular}

Not surprisingly, growth in LAC-7 also experienced sharp reduction. GDP growth fell from an average of 4.4 percent per year between 1991 and the year ending in II-1998, when international financial resources were abundant and cheap, to 0.5 percent between 1999 and 2002 after the Sudden Stop (see Figure 3h). Again, the reduction in growth rates was both synchronized and widespread. As Table 3 illustrates, growth reversals occurred in every country of the region, ranging from 11 percentage points in Argentina and 6 percentage points in Chile and Venezuela, to 1.5 and 0.1 percentage points in Brazil and Mexico, respectively.

\section{The Chilean Experience}

As noted, Chile was also affected by a severe Sudden Stop in the aftermath of the Russian crisis and experienced a hard landing as a result. The anatomy of Chile's 
macroeconomic adjustment following the Sudden Stop was qualitatively and quantitatively a carbon copy of the average Latin American country described above. Figure 4 illustrates its main characteristics.

In the aftermath of the Russian crisis, Chile also suffered a large and persistent increase in the cost of external financing and a collapse in asset prices and currency values. Interest rate spreads more than tripled, albeit from lower levels than those of the average LAC-7 country, from 120 basis points prior to the Russian crisis to 390 basis points in October 1998 (see Figure 4a).

The tightening in monetary and credit conditions further resulted in a severe drop in asset prices: the stock market in Chile collapsed by 37 percent between II-1998 and IV-2002 compared to 48 percent in LAC-7, after having already experienced a substantial decline since the Asian crisis (see Figure 4b).

The severe tightening in monetary and credit conditions and the reduction in the value of collateral also precipitated in Chile a Sudden Stop in external financial flows that actually turned negative. As a result, the Sudden Stop was accompanied by a sharp and persistent external financial deleveraging on the part of households and firms. After the Russian crisis, external financial flows fell from a cumulative total of 20 billion (real) dollars to a cumulative total of 10 billion dollars a 47 percent reduction (see Figure 4c). Likewise, domestic bank credit flows to the private sector came to a Sudden Stop but turned negative for only a brief period of time (see Figure 4d). Although the stock of bank credit continued to grow, it did so at substantially lower rates. Bank credit growth declined from an average of 13.5 percent in the period I-1991 to II-1998 to 2.9 percent in the aftermath of the Russian crisis.

Chile, like the average LAC-7 country, also required a very protracted period of external financial deleveraging and a substantial improvement in international financial conditions (i.e., a large reduction in US interest rates) in order for its interest rate spreads and the cost of external financing to return to pre-Russian crisis levels.

The Sudden Stop in capital flows and external financial deleveraging in Chile also had its counterpart in a sharp current account adjustment and real currency depreciation. The current account went from a deficit of 6.5 percent of GDP in the year ending in II-1998 to virtual balance one year later, a similar adjustment to LAC-7 overall but in a shorter time span (see Figure 4e). From June 1998 to December 2002, Chile's currency depreciated by close to 50 percent vis-à-vis the US dollar, compared to 70 percent in LAC-7 (see Figure 4f). 
Figure 4. Sudden Stop and Macroeconomic Adjustment in Chile, 1990 - 2002

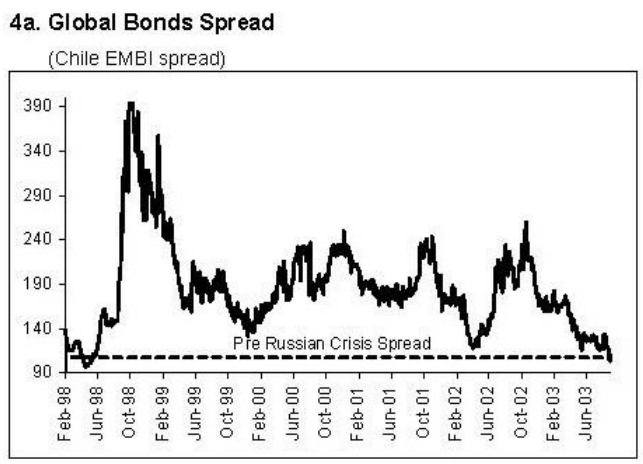

4b. Stock Prices

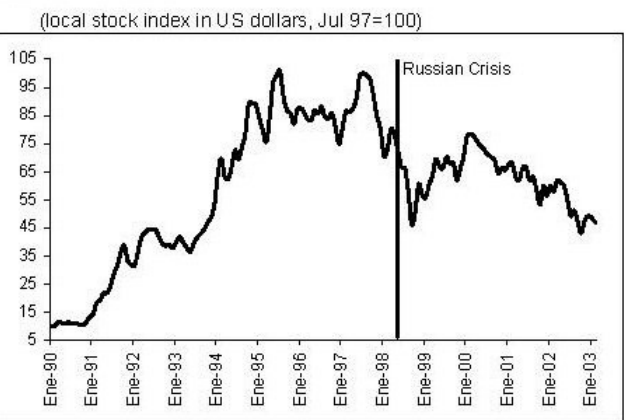

4c. External Financial Flows

(non-FDI flows + E\&O, in billions of 2003 US dollars)

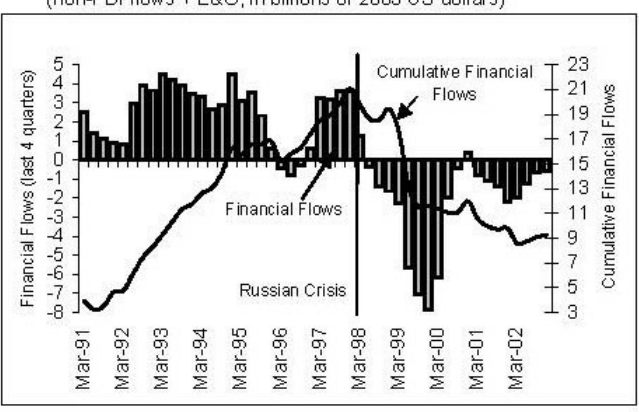

4d. Domestic Bank Credit Stocks and Flows

(to the private sector, in billions of 2002 Chilean Pesos)

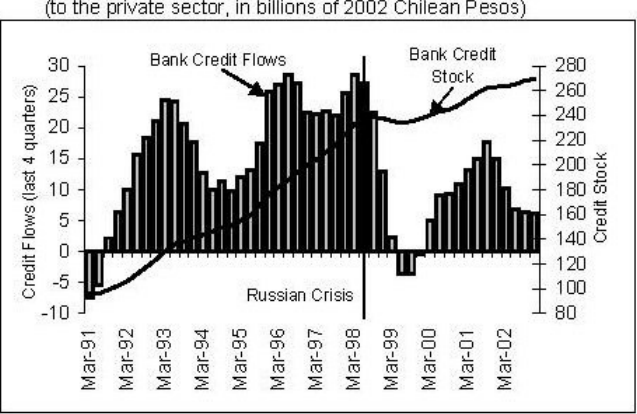

4e. Current Account Adjustment

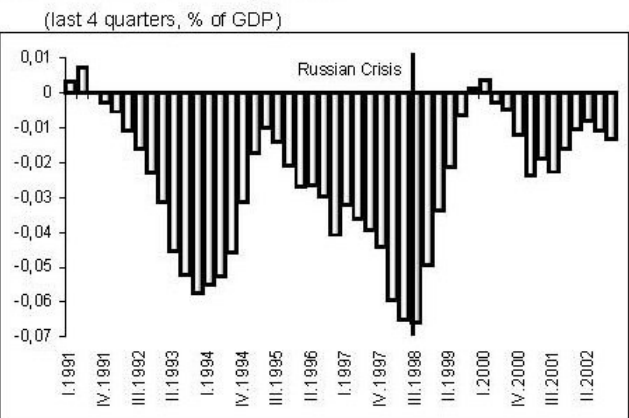

4f. Real Exchange Rate Adjustment

(vis-à-vis US dollar, Jun $98=100$ )

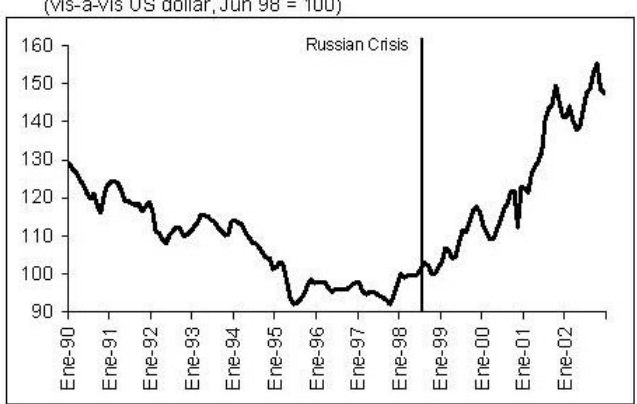

4g. Investment, 1990-2002

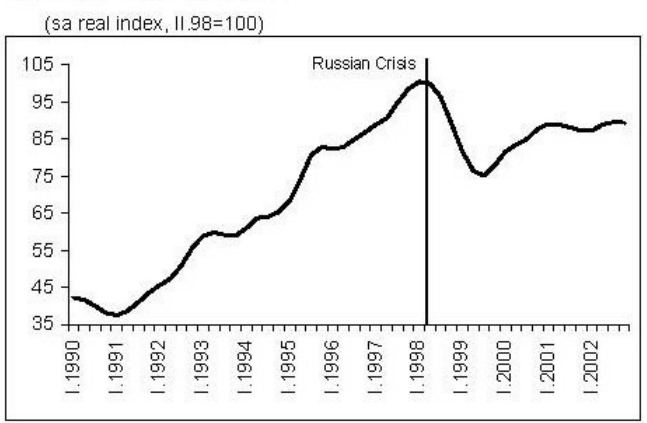

4h. Economic Activity, 1990-2002

(GDP, sa real index II.1998 $=100$ and annualized qoq growth rate)

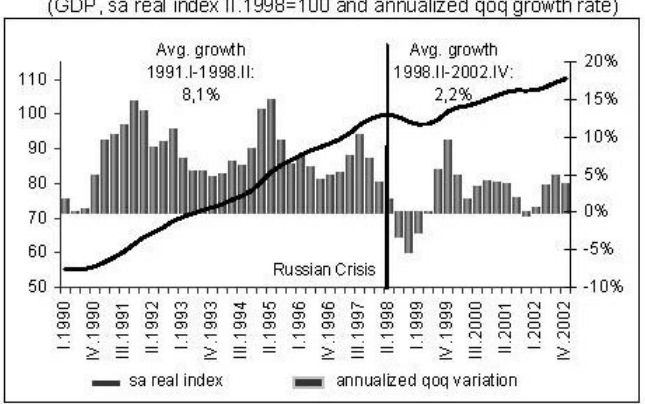

Data sources: Central Bank of Chile 
Finally, as in the average LAC-7 country, Chile's financial deleveraging and large current account adjustment were obtained through a severe and sustained reduction in investment. Investment declined by 23 percent in the immediate aftermath of the Russian crisis, and by the fourth quarter of 2002 it was still 12 percent below its pre-Russian levels (see Figure 4g). Between 1999 and 2002 average growth in investment was negative, and the investment ratio fell from 27 percent of GDP in 1997, prior to the Russian crisis, to 21 percent of GDP in 2002; this reduction of 6 percentage points explains the bulk of the current account adjustment (see Table 2). The drop in investment ratios was associated with a correspondingly sharp reduction in growth rates (Figure 4h). Growth in Chile fell from an average of 8 percent per year between 1991 and 1997 to 2 percent per year between 1999 and 2002, after the Sudden Stop.

In summary, the evidence strongly suggests that the poor growth performance of the region in the late 1990 s and early 2000 is the result of the macroeconomic adjustment set in motion by the Sudden Stop in capital flows following Russia's crisis. As credit dried up and existing degrees of leverage could not be sustained, LAC-7 economies went through a protracted period of relatively low investment as households and firms adjusted their balance sheets to the new situation. Every major country in LAC-7 was affected to a greater or lesser degree (with the notable exception of Mexico who is tightly linked to the US business cycle), including Chile, by far the best performer in the region.

\section{From Macro-Adjustment to Financial Crisis and Economic Collapse: The Polar Cases of Chile and Argentina}

However hard the landing and painful the adjustment, the Chilean economy experienced no financial crisis and economic collapse, as did Argentina's economy. This is puzzling in light of the fact that the Sudden Stop in capital flows in Chile and Argentina from II1998 to II-2001 - the period prior to the beginning of the bank run in Argentinadisplayed a similar time pattern and if anything, was larger in Chile than in Argentina (see Figure 5).

A cold spell affects different people in different ways: some catch a mild cold, while others end up at the hospital. Clearly, the outcome will depend on the physical strength or fragility of the person affected. Similarly, a Sudden Stop in capital flows 
Figure 5. Sudden Stop and Economic Performance in Argentina and Chile

5a. Sudden Stop in Argentina and Chile

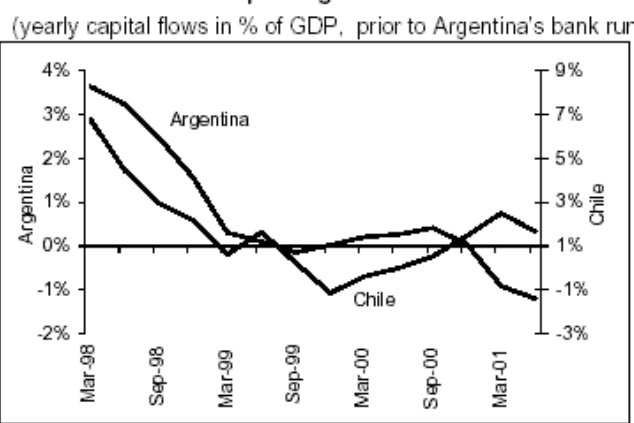

5b. Sudden Stop and GDP in Argentina and Chile (sa real indices, II.1998=100)

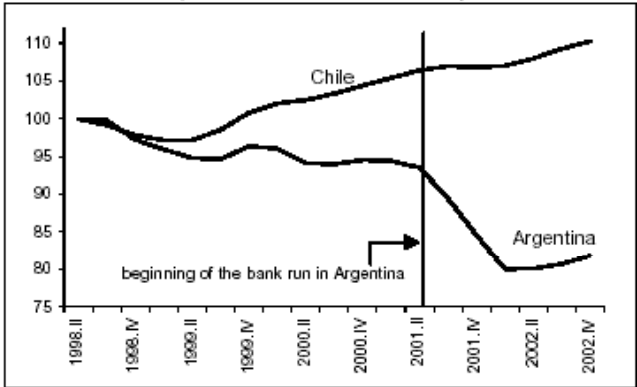

5c. Sudden Stop and Investment in Argentina and Chile (sa real indices, II.1998 $=100$ )

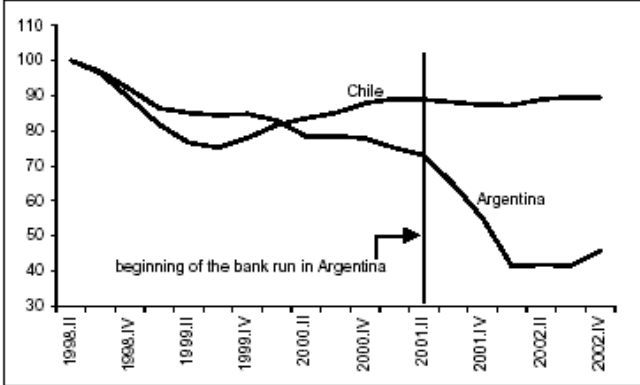

Data sources: corresponding Central Banks 
originating in external factors can have a very different impact depending on the strength or the vulnerability of each economy.

In this section we identify two key domestic factors that contribute to attenuate or intensify the effects of a Sudden Stop. These are: trade openness and Liability Dollarization. ${ }^{13}$ In what follows we discuss the mechanisms through which these factors operate, focusing on the case of Argentina.

\section{Openness}

As we showed in the previous sections, a Sudden Stop in capital flows was typically accompanied in the average LAC-7 country (Chile included) by a rapid and large adjustment in the current account, and by a large real depreciation of the domestic currency.

Openness is an essential link in the chain mapping an external liquidity shock to a financial crisis and an economic collapse. The reason is that the change in the real exchange rate to accommodate a Sudden Stop in capital flows is larger in a closed economy than in an open economy. ${ }^{14}$

As illustrated in Table 4, Chile's economy prior to the Russian crisis and the Sudden Stop was approximately 50 percent more open than that of Argentina if we use the share of tradables in GDP as our measure of openness: Chile's tradable sector averaged 35 percent of GDP compared to 24 percent in Argentina for the period 19911997 prior to the Russian crisis. ${ }^{15}$ Although Argentina's current account deficit prior to the Sudden Stop was smaller than Chile's (4.7 percent as opposed to 6.5 percent), due to its relatively closed economy Argentina would have required a larger real depreciation than Chile in order to eliminate the current account deficit. This is so because

${ }^{13}$ Calvo, Izquierdo and Mejía (2004) perform formal econometric tests on the role of openness and financial dollarization as determinants of Sudden Stops.

14 For a formal proof in the context of a simple model see Calvo, Izquierdo and Talvi (2003). The intuition is that in the short run, i.e., when the supply of tradables is relatively fixed, an adjustment of the current account of any given size requires a larger proportional reduction in domestic absorption of tradables the smaller the supply of tradables relative to domestic expenditure of tradables. Under standard assumptions of preferences (homotheticty), the absorption of non-tradables must fall by the same proportion as tradables. In the short run, i.e., when the supply of non-tradables is relatively fixed, the required change in the equilibrium real exchange rate will be larger, the smaller the supply of tradables relative to domestic expenditure on tradables.

15 The share of tradables in GDP is proxied by the participation of the primary and manufacturing sectors in GDP. Traditional measures of openness, i.e., the share of imports plus exports as a share of GDP, averaged 56 percent in Chile and 19 percent in Argentina for the period 1991-1997, prior to the Russian crisis. 
Argentina's current account deficit, when measured in percent of imports prior to the Sudden Stop, was 60 percent larger than Chile's. Hence, Argentina may have required a real depreciation of 75 percent after the Sudden Stop if we scale Argentina's required depreciation to Chile's observed depreciation (and assume that the elasticity of substitution in consumption between tradables and nontradables is about the same in both countries). Let us recall that Chile eliminated its current account deficit and its currency depreciated by 48 percent after the Sudden Stop. ${ }^{16}$

Table 4. Sudden Stop, Openness and Real Exchange Rate (RER) Adjustment in Argentina and Chile

\begin{tabular}{|c|c|c|c|c|}
\hline \multirow[b]{2}{*}{ Country } & \multirow{2}{*}{$\begin{array}{l}\text { Openness } \\
\text { (share of tradables in GDP, avg 91-97*) }\end{array}$} & \multicolumn{2}{|c|}{$\begin{array}{l}\text { Current Account Deficit } \\
\text { Year to II. } 1998\end{array}$} & \multirow{2}{*}{$\begin{array}{l}\text { Required change in the equilibrium RER* } \\
\text { (scaled to Chile's observed depreciation) }\end{array}$} \\
\hline & & $\%$ of GDP & $\%$ of imports & \\
\hline Chile & $35 \%$ & $6.5 \%$ & $22 \%$ & $48 \%$ \\
\hline Argentina & $24 \%$ & $4.7 \%$ & $36 \%$ & $75 \%$ \\
\hline
\end{tabular}

*The share of tradables in total production is proxied by the participation of the primary and manufacturing sectors in GDP.

* See Calvo, Izquierdo, Talvi (2003).

Under normal circumstances, a real devaluation would be part of the solution for an economy that requires substantial external adjustment. However, under extensive Liability Dollarization a large devaluation was bound to be part of the problem, not part of the solution.

\section{Liability Dollarization}

Figure 6a illustrates that private debt in Argentina was highly dollarized. ${ }^{17}$ Prior to the Sudden Stop, 80 percent of private debt, whether domestic or foreign, was denominated in US dollars compared to 38 percent in Chile. The high dollarization of private debt implied large financial mismatches in the balance sheets of Argentinean households and firms, since only 25 percent of productive activities are in the tradable sector, and therefore, potentially capable of generating earnings in hard currency. In contrast, Chile's tradable sector is much larger (the share or tradable goods in GDP prior to the Sudden Stop was 35 percent) and similar in size to the share of dollar debts in total

\footnotetext{
${ }^{16}$ See Calvo, Izquierdo and Talvi (2003) for a formal derivation of the relative size of the required real depreciation by Argentina and Chile to eliminate the current account deficit.

${ }^{17}$ Private debt is defined as domestic bank credit to the private sector plus foreign lending to the nonfinancial domestic private sector.
} 
Figure 6. Sudden Stop, Dollarization, Financial Crisis and Economic Collapse: Argentina in the Light of Chile

6a. Dollarization of Private Debt

(share of dollar denominated debt in total debt)

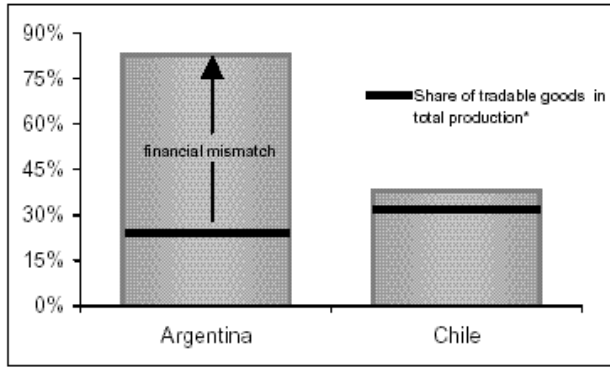

6c. Dollarization of Public Debt

(share of dollar denominated debt in total debt)

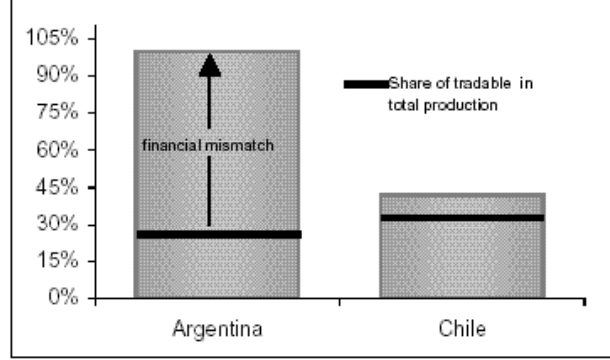

6b. Argentina's Private Debt at New Equilibrium Real Exchange Rate (RER), in \% of GDP

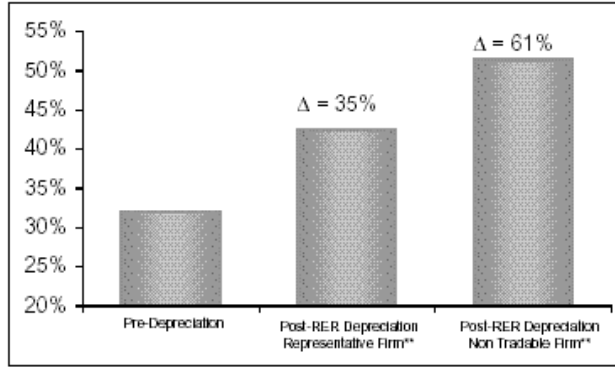

6d. Argentina's Public Debt at New Equilibrium Real Exchange Rate (RER), in \% of GDP

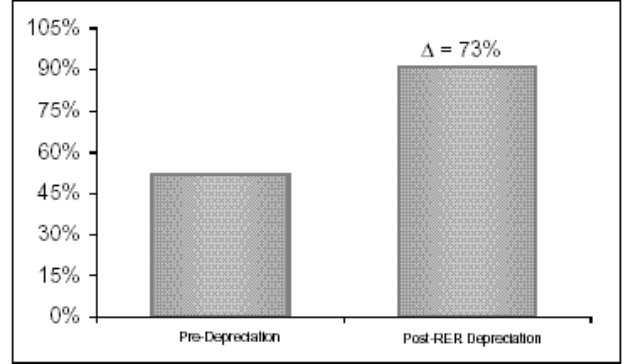

6e. Bank Run, Credit Crunch and Economic Collapse in Argentina

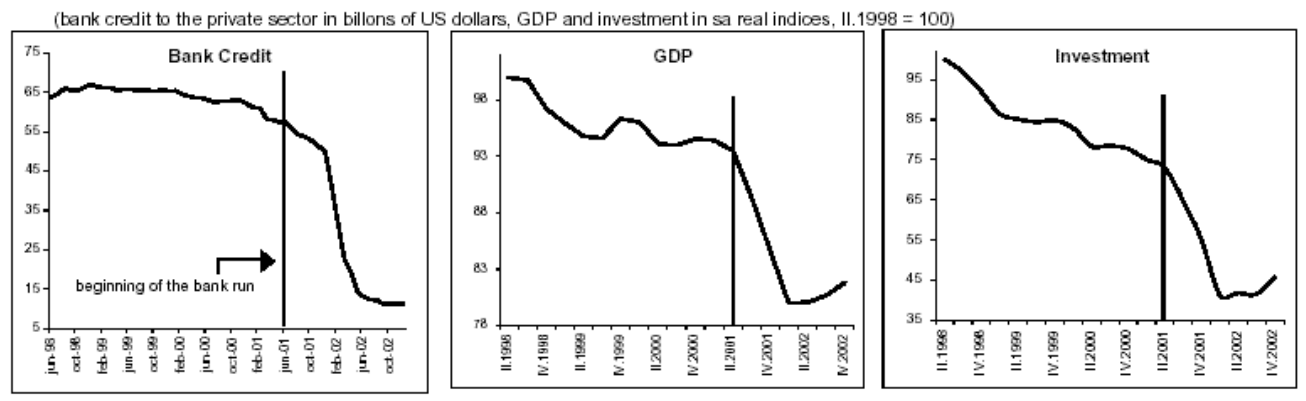

Data sources: corresponding Central Banks and own estimations

*The share of tradable goods in total production is proxied by the share of the primary and manufacturing sectors in GDP.

${ }^{\star}$ The representative firm and the non-tradable firm are assumed to generate 75 percent and 100 percent, respectively,

of their income in domestic currency. 
private debt. Hence, the aggregate balance sheet of Chile's private sector was likely to be much less sensitive to movements in the real exchange rate. ${ }^{18}$

In the presence of these very large financial mismatches, a real devaluation of 75 percent in Argentina implied a huge revaluation in the value of private debts. For the typical debtor, with 80 percent of its liabilities denominated in US dollars and one quarter of its income generated in US dollars, the ratio of the stock of debt relative to income would be expected to increase by 35 percent. For a debtor whose income was 100 percent in local currency the situation would be even worse: the ratio of debt to income would be expected to rise by 61 percent (see Figure 6b).

Let us pause for one second to stress why a large expected real devaluation and the implied revaluation of private debt stocks was bound to create severe financial stress. After the Sudden Stop, interest rate spreads for emerging economies skyrocketed and the value of collateral plummeted, signaling the unsustainability of outstanding debt stock. This situation was bound to be exacerbated by currency devaluation (another consequence of Sudden Stop), by increasing private debt ratios even further. This "double whammy," namely, the sharp rise in external financing costs and the revaluation in the stock of private debt, forces a much larger adjustment in debt stocks and sets in motion a potentially disruptive credit crunch (i.e., the inability to roll over existing stocks of debt) that could strangle investment and production.

Even if only the group of firms with balance sheet mismatches runs into financial trouble, i.e., is hit by the inability to rollover its stock of debt, much of the rest of the economy becomes suspect. This is the case because, in most market economies, inter-enterprise credit plays a prominent role in business transactions. In such an environment, credit to firms whose debts would have automatically been rolled over is conditioned on passing more in-depth viability tests. The latter, in turn, is a costly information-gathering exercise, and more so during a crisis, because it requires information about the inter-enterprise credit network to which the firm in question is connected. Like highway congestion caused by an accident, which can stop the flow of traffic, this may represent a major negative supply shock. ${ }^{19}$

Under these circumstances of severe financial stress, the public sector could have been part of the solution by, for example, "collateralizing" private debts (as Korea

\footnotetext{
${ }^{18}$ For micro evidence on the absence of any significant balance sheet mismatches in Chile see Cowan, Hansen and Herrera (2004).

${ }^{19}$ See Calvo (2000) for a discussion.
} 
did in 1997), by implicitly offering future tax revenues as collateral to prevent or mitigate the credit crunch of the private sector. But Argentina's public sector was bound to be part of the problem, not part of the solution. Close to 100 percent of Argentina's public debt, domestic and foreign, was denominated in US dollars, compared to 44 percent in Chile (see Figure 6c). Thus, a real devaluation of 75 percent-which, as argued above could have been called for by the Sudden Stop-would be expected to result in an increase of the public debt/GDP ratio from 54 to 93 percent (see Figure 6d).

In order to sustain those higher levels of public debt under tighter external financial conditions, Argentina's public sector would have been required to significantly increase its primary surplus in a sustained and credible manner to the tune of 3 percentage points of GDP (or 15 percent of government expenditures). ${ }^{20}$ Since government expenditures largely consist of wages and pensions it is close to impossible for a democratically elected government to engineer explicitly such a reduction through the normal budget process. ${ }^{21}$ The alternative, i.e., to increase taxes on the private sector at the time when the private sector was also experiencing a severe credit crunch, simply meant plugging one hole by opening another. Clearly, the expected revaluation of debts, both private and public, was a national problem, and the private sector could not be counted on to bail out the public sector through higher taxes, and the public sector could not be counted on to bail out the private sector by socializing private debts. Under these circumstances, the credit crunch would be felt simultaneously by both the private and the public sector. Given the sheer magnitude of the problem caused by the "double whammy" and the inability to continue rolling over existing stocks of debt, it was unlikely that the adjustment in debt stocks would not have been expected to include some kind of debt restructuring, both public and private.

Let us now turn to the banking sector, a major factor in spreading the crisis across the economy. In the case of Argentina, bank assets consisted primarily of loans to the private and public sectors. Thus, financial trouble of the sort described above implied a severe deterioration of the quality of banks' loan portfolio. As it became increasingly clear that the Sudden Stop was systemic and persistent, and that a realignment of the exchange rate in Argentina was bound to be large and close to

\footnotetext{
${ }^{20}$ See Calvo, Izquierdo and Talvi (2003).

21 Adjustments of this size, and even larger, in public sector wages and pensions have been regularly observed in Latin America. However, they are typically engineered through an "inflationary shock" that dilutes the real value of nominal wages and pensions rather than through an explicit decision of the government through the budgetary process.
} 
inevitable, the seeds of a bank run were sown. From the perspective of depositors, there was nobody around to bail them out in the event of a large devaluation, and therefore they ran for the exits. From February to December 2001, when the "corralito" was implemented, Argentina's banks lost close to 50 percent of their deposit base. ${ }^{22}$ The bank run exhausted the central bank's international reserves, and the worst nightmare finally came true: the Convertibility regime, i.e., the fixed one-to-one peg to the US dollar, was abandoned and the peso experienced a very large depreciation. Not surprisingly, bank credit to the private sector also collapsed, along with the deposit base, and there was a huge collapse of investment and economic activity. GDP and investment fell by 25 percent and 70 percent, respectively, from (the year to) III-1998 to (the year to) III-2002, when they reached a minimum (see Figure 6e).

Before concluding this section, a note on the Convertibility regime is in order. Many economists believe that had Argentina decided to abandon Convertibility and devalue its currency early on, the protracted recession and ultimate financial crisis and economic collapse could have been avoided or largely attenuated. Chile's case is often cited as an example of a country that recognized early on that the currency needed to be adjusted in the aftermath of the Sudden Stop and successfully did so.

Although we acknowledge these Keynesian elements might have played a role in the early stages or Argentina's recession, they are not at center stage in explaining the ensuing collapse. Contrary to popular opinion, we believe that whatever the flaws of the Convertibility regime (and there may be many), ${ }^{23}$ the exchange-rate regime was a side show in this crisis. Had the Argentinean authorities decided to abandon it by engineering an early devaluation of the currency in the immediate aftermath of the Sudden Stop, the financial crisis would have occurred earlier. This is the case because the key problem was the real devaluation per se (and the revaluation of private and pubic debts it implied). In our view, the delay in abandoning the Convertibility regime and in recognizing (what turned out to be) an inevitable realignment of the Argentinean currency was not the main cause of the crisis. Rather, the crisis was the consequence of Argentina's very high Liability Dollarization and the large real devaluation required by the Sudden Stop. This explains why devaluation of the Argentinean currency was delayed until it became patently obvious that there was no other choice.

\footnotetext{
22 The "corralito" was the popular name given to the prohibition dictated by the government to withdraw money from bank accounts, except for very small and predetermined weekly amounts.

${ }^{23}$ See Calvo (1999b).
} 


\section{Reflections on Policy}

The recent crop of crises in emerging economies has revealed the importance of external financial factors, confirming once again the findings in Calvo, Leiderman and Reinhart (1993). Therefore, this section will discuss policy responses to systemic shocks originating in international financial markets. We first offer some remarks on a variety of crisis prevention policies that have taken center stage in current policy debates, namely, self-insurance, capital controls, the exchange rate regime and dedollarization. In addition we discuss the role of trade policy in crisis prevention, which emerges naturally from our previous analysis. We will then discuss the role of fiscal and interest rate policy in dealing with the crisis after it has occurred. Finally, we conclude this section with some brief remarks on what can be done at the global level to prevent or reduce the likelihood of systemic financial shocks affecting EMs.

\section{Crisis Prevention Policies}

The relevance of systemic shocks-shocks that apply to more than one EM economy at a time-became apparent after the 1998 Russian Crisis, which brought about a Sudden Stop (of capital inflows) in several countries, despite Russia's small role in trade and financial markets. What can a single country do to offset such a negative shock? Typically, policymakers come forward asserting that their country is different-and, typically, this does not work. Multilateral financial institutions also join the chorus in a typically vain attempt to stave off a crisis, only to be quickly and rudely dismissed by the market (unless they are prepared to put enough money on the table). As we will discuss below, standard policies are not very effective either. Credit dries up, so expansive fiscal policy is unfeasible (unless, once again, multilateral financial institutions or generous donors come forward with the necessary finance). Low central bank interest rates do not generate more credit (unless the central bank is prepared to spend its international reserves). In sum, standard policy is not effective unless some form of new credit is made available.

What can an individual country do to attenuate the effects of systemic crisis prior to crisis? Here the options are more varied, although by no means easy or costless. 
1. Self Insurance. Let us focus on a Sudden Stop, i.e., a credit crunch suffered by the country as a whole. If the government is over-indebted, the public sector is part of the problem. However, if public debt is small, then the public sector could help to ameliorate the credit squeeze by tapping multilateral financial institutions and putting up future tax revenue as collateral (as Korea did in 1997); or, equivalently, by employing its international reserves (as Hong Kong and Brazil did in 1998 and 2002, respectively). These observations suggest the following policy alternatives prior to crisis: (a) contingent credit lines from private/public international institutions, and (b) a War Chest of international reserves. We will now say a few words about them.

(a) Contingent Credit Lines. They are effective complements to international reserves, and were implemented by Argentina and Mexico. However, these lines tend to dry up as crisis looms. Moreover, the amounts are typically insufficient to prevent a sharp current account adjustment.

(b) War Chest. This is becoming a popular idea. The example that is usually mentioned is the Chilean Copper Stabilization Fund, which is supposed to grow during the expansion phase of the business cycle, and fall during downswings. The Chilean system does not fully address systemic shocks, since in principle the latter are not necessarily correlated with domestic business cycles. However, the basic idea is the same: minimize adjustment costs during downturns, and, especially, avoid having to implement tight fiscal policy during recessions. One problem with War Chests is that the ruling party may have strong incentives to violate its operating rules and sacrifice the War Chest for the sake of popularity at the polls. This observation is particularly relevant for a case in which the War Chest is created to bail out the banking system. In that case the sums involved could amount to 20-30 percent of GDP. Thus, we feel that a War Chest is unlikely to stand on its own. It will likely have to be complemented with Contingent Credit Lines, because the latter involve third parties that could better ensure compliance with operating rules. 
A problem faced by the types of policies described above is moral hazard. Anticipating a bailout, the private sector will likely change its behavior, possibly offsetting the effects of the bailout. Thus, bailouts must be made costly, especially for those agents who will be their direct beneficiaries. ${ }^{24}$

2. Capital Controls. There are few other topics that are as badly understood as the effect of capital controls on the probability of financial crises, more specifically, Sudden Stops. A common, and misleading, intuition is that if one prevents short-term ("hot") capital from flowing in, then capital will not gush out, and a Sudden Stop will thus be prevented. Plausible as it may sound, this intuition is wrong for more than one reason. In the first place, capital outflow can take place even in the absence of capital inflow. For example, exporters could keep export proceeds in a foreign bank instead of bringing them home, and multinational firms could increase the rate of profit repatriation or use financial transactions that imply capital outflows to hedge the risks of immobile assets in their balance sheets. Second, a Sudden Stop entails lower capital inflows, not necessarily capital outflows. Thus, a Sudden Stop would take place if Foreign Direct Investment, FDI, slows down (as happened in Peru in 1998), even though FDI is the polar opposite of hot capital. This shows, incidentally, that not even effective controls on capital outflows (as in Malaysia in 1997) could prevent Sudden Stop. Third, as shown in previous sections, empirical evidence cast serious doubts on the effectiveness of controls on capital inflows. After 1998, Chile suffered the largest Sudden Stop in Latin America, despite having consistently, and for an extended period of time, imposed controls on capital inflows. Furthermore, it is possible to conceive of circumstances in which the imposition of controls may exacerbate the extent of a Sudden Stop, because the government would have revealed its predisposition to meddle with the market.

3. Exchange Rate Regime. This is another topic where confusion is king. Some seem to think that crises could be entirely wiped out if the exchange rate was free to float. This is an extreme view, and an easy one to dismiss. However, it is perhaps fair to say that most observers believe that pegged exchange rates are dangerous for EMs. Interestingly, while the debate leans against fixed exchange rates, accession countries in Europe are eagerly queuing up to join the euro, and China-with a splendid sustained growth record-has pegged its currency to the US dollar since 1995. Moreover, not even the pro-floaters appear to be disturbed by the fact that economies so

\footnotetext{
${ }^{24}$ See IADB (2005).
} 
geographically diverse as the regions of the US have only one currency, and are proud and happy to do so. Although California has gone through a deep recession in recent years we have never heard a respectable pro-floater say that what California needs is to issue a new currency and devalue!

Exchange rates have recently been discussed in Calvo and Mishkin (2003), and we have little to add here. The bottom line is that exchange rates are a sideshow. Issues like institutions and credibility take the center stage. Sudden Stop episodes involve a sharp drying up of credit, bringing about severe domestic repercussions, especially if the economy is highly "Liability Dollarized" (i.e., foreign exchange-denominated debts). Under those circumstances, a floating exchange rate is of little help and may even aggravate the crisis. Calvo, Izquierdo and Mejía (2004) show that the probability of a Sudden Stop increases with Liability Dollarization (more precisely, Domestic Liability Dollarization, i.e., foreign exchange debts to the domestic banking system), while the exchange rate regime does not appear to be a contributing factor.

4. De-dollarization. As noted, Liability Dollarization appears to increase the chances of a Sudden Stop. Thus, the question arises, is there a way to remove the dollarization scourge? We probably reflect conventional wisdom on this matter in saying that Liability Dollarization is likely a consequence of many years of monetary mismanagement. Thus, it is unlikely that it will go away as a result of actions taken by present policymakers, unless there is an assurance that future policymakers will not revert to business as usual. Forceful de-dollarization on the other hand, is likely to result in a drastic shrinkage of the financial system and a reduction in the maturity of deposits.

A possibility that has received some attention is to try to steer the domestic financial system away from indexing to a foreign currency and towards some domestic price level. A successful example in Latin America is the Chilean UF (Unidad de Fomento). In Chile most financial and formal-sector wage contracts are UF-indexed. This allowed Chile to carry out a large real devaluation after 1998 without disrupting the domestic capital market. Can this be replicated in other countries, and is this always a desirable policy? The first part of the question does not have a promising answer. In the first place, Chile was never heavily dollarized; even so, it took about 30 years to make the UF operational. ${ }^{25,26}$ As to the second part of the question, "Is it desirable?" we do not have a good answer yet. Financial problems arise when there is a mismatch

\footnotetext{
${ }^{25}$ See Landerretche and Valdes (1997).

${ }^{26}$ Bolivia recently attempted to adopt an UF-type system to de-dollarize its banking system to no avail.
} 
between the denomination of assets and liabilities at financial institutions and/or firms in general, and Liability Dollarization is a clear case of mismatch in the non-tradables sector. But any index is likely to be imperfect when the economy is faced with a large change in relative prices. Thus, for example, as a result of Sudden Stop housing prices are likely to show a precipitous fall. Since the index will only partially reflect housing prices, mortgage obligations are bound to surge relative to housing values-causing financial difficulties, as households will have much lower incentives for honoring their housing financial obligations.

5. $\quad$ Trade Policy. As noted above, given the current account deficit, the change in relative prices brought about by Sudden Stop is in inverse relation to the degree of openness. Thus, the larger the tradables sector, the less likely that a Sudden Stop will generate serious financial problems. Actually, for the purposes of this discussion "tradables" are goods that could be quickly transformed into exports when there is a collapse in domestic demand. Thus, a better term for "tradables" in this context is "exportables." Evidence of exportability is offered by Chile after the 1998 Russian crisis: exports in Chile contributed to 50 percent of the current account adjustment. In sharp contrast, in Argentina 98 percent of the current account adjustment after 1998 (and prior to the bank run in II-2001) was triggered by a reduction in imports.

These observations provide new support for trade opening. Here the argument is not the standard one in trade theory, in which issues like comparative advantage or product variety are at center stage. Rather, the argument is that economies with a large exportables sector will exhibit stable real exchange rates-thus lowering the deleterious incidence of Liability Dollarization. What is important in this context is that tradable goods can quickly be transformed into exports-and for this, availability of trade credit is essential. Recent episodes, however, show that trade credit can dry up as quickly as other types of credit. This is very disconcerting because one would expect exports to be good collateral for international creditors. Recent conversations with bankers and policymakers in Brazil and Uruguay, however, indicate that exports' value as collateral is jeopardized by the expectation of disarray after a Sudden Stop. For example: (a) strikes and social upheaval may prevent exports from reaching the port, making them non-exportable, (b) the government may impose foreign exchange controls that either impede the repayment of external debt or make it extraordinarily onerous. Therefore, under those circumstances, to make tradable goods exportable the government will have 
to be prepared to dip into its War Chest or Contingent Credit Lines to support the export sector. $^{27}$

\section{Post- Crisis Policies}

The debate on how fiscal and interest rate policy should be conducted after crisis has been heated. Should fiscal and monetary policy be tight, as usually recommended by the IMF? Or should these policies be loose, as recommended by authors like Joseph Stiglitz, a harsh critic of IMF policies during the Asian crisis? ${ }^{28}$ Although we do not intend to resolve the striking differences of opinion on this issue here, some comments are in order.

$1 \quad$ Fiscal Policy. If the government does not have the resources or cannot access the capital market, there is little the public sector can do to alleviate the situation. Thus, under these conditions, it would be impossible to implement expansive fiscal policy. This, incidentally, does not imply that tight fiscal policy-beyond what is strictly required by capital market conditions - is desirable either. The only exception would be if tight fiscal policy improves the economy's credibility and facilitates capital market access by the private sector. ${ }^{29}$ This is hard to determine in practice, but we believe that the success of super-tight fiscal policy depends on whether the crisis is systemic or localized. If the crisis is systemic, then super-tight fiscal policy is likely to be unnecessarily contractionary, undermining policy credibility and aggravating the crisis. $^{30}$ On the other hand, if the crisis is localized, then fiscal super-adjustment might help, particularly if it is accompanied by generous funding from multilateral financial institutions or it takes place during a favorable phase in the capital market for EMs.

$\underline{2} \quad \underline{I n t e r e s t ~ R a t e ~ P o l i c y . ~ L o w ~ i n t e r e s t ~ r a t e s ~ a r e ~ l i k e l y ~ n o t ~ t o ~ b e ~ i m p l e m e n t a b l e ~ u n l e s s ~}$ the country has a War Chest, Contingent Credit Lines or a generous transfer from the international community. However, as with fiscal policy, there is the question of how tight monetary policy should be. Furman and Stiglitz (1998), for example, are skeptical

\footnotetext{
27 The central bank of Brazil extended credit to the export sector in 2002, in the midst of a Sudden Stop that was partly provoked by uncertainty regarding the political transition about to take place in December. ${ }^{28}$ See Stiglitz (2002).

29 This was the strategy followed by Argentina in August 1996, when Minister Cavallo was fired by President Menem, and the new minister (Roque Fernandez) had to show he was a fiscal conservative visà-vis the capital market. The strategy seems to have been successful, but partly because external financial conditions were favorable, as will be discussed below.

${ }^{30}$ We conjecture that the failure of Argentina's 2000 fiscal adjustment program had a great deal to do with the fact that it was carried out in the midst of the Sudden Stop that affected many EMs after the 1998 Russian crisis.
} 
of super-tight monetary policy; and we agree, especially after Sudden Stops. A Sudden Stop breaks the link between domestic and international credit markets, at least momentarily, thus making it possible for super-tight monetary policy to be contractionary. ${ }^{31}$ Therefore, policymakers have to sail the narrow stretch between the Scylla of contraction and the Charybdis of inflation and monetary disarray-by no means an easy task!

\section{Global Policies}

Our previous discussion suggests that even under the best of circumstances systemic shocks cannot be entirely palliated by domestic policy. Is there something further that can be done at a global level to prevent a systemic shock?

The answer to the question depends, of course, on the causes of systemic shocks. Take, for example, the case in which credit to EMs dries up as a result of a liquidity crunch at the center of the capital market, a leading explanation for the spread of the 1998 Russian crisis. ${ }^{32}$ In such a case the obvious solution is to relieve the global liquidity crunch by, for example, lowering US and EU interest rates (as eventually happened after the Russian crisis). The problem is that US/EU central banks are not supposed to react to liquidity problems that affect other economies. Thus, liquidity relief may arrive when the systemic shock is already in full swing and has already caused irreversible damage in EMs. This demonstrates the need to creating a global central bank to manage global liquidity problems. Unfortunately, however, a moment's reflection shows that such a project is fraught with forbidding regulatory problems, stemming from national sovereignty constraints. A more modest proposal is the creation of an Emerging Market Fund, EMF, which would attempt to stabilize the price of EM bonds in case of a global liquidity crunch. ${ }^{33}$

The main difference between these proposals and current international arrangements is that IMF liquidity assistance in the event of a credit crunch to EMs is targeted at individual countries, rather than at financial intermediaries suffering from a

\footnotetext{
${ }^{31}$ Calvo and Coricelli (1992) discussed this issue in regard to the IMF 1990 Poland stabilization plan, where monetary policy was extraordinarily tight. For example, on January 1, 1990, the start of the stabilization program, the National Bank of Poland increased interest rates in zlotys from 7 to 36 percent per month! Calvo and Coricelli (1992) argue that this policy was responsible for the sharp output decline in 1990, because Poland had no access to international capital markets (hence, it was operating under conditions similar to those that prevail under Sudden Stop).

${ }^{32}$ See Calvo (1999a).

${ }^{33}$ See Calvo (2000) for a discussion.
} 
liquidity crunch. A global Central Bank or EMF, in contrast, would mitigate the liquidity crunch of financial intermediaries in EM bonds. This is akin to the actions undertaken by a Central Bank when confronted by a bank run that would result in a credit crunch as banks recall their outstanding loans to repay depositors: liquidity is directly provided to the banks and not to the bank's individual debtors.

Other proposals to mitigate the impact of systemic shocks emphasize the role of multilateral institutions in fostering the development of financial instruments to allow for a more efficient international risk sharing. One such proposal, advanced by Eichengreen and Hausmann (2003), intended to attenuate the incidence of Liability Dollarization claims that multilateral institutions should lend a portion of their funds to EMs in inflation-indexed instruments denominated in their own currency. Multilateral institutions in turn would issue debt instruments denominated in an inflation-indexed basket that would be placed with institutional investors. The implied basket would suffer less from idiosyncratic risk and, therefore, may enjoy higher liquidity than the country-specific bonds.

Proposals such as the SDRM (a sort of international bankruptcy proceedings sponsored by the IMF) or the inclusion of collective action clauses in sovereign bond issues, are intended to an efficient resolution of a sovereign debt crisis once it has occurred. Such mechanisms for orderly restructurings of sovereign defaults have several limitations that have been extensively discussed by the international financial community. For our purposes it is sufficient to say that proposals along these lines could have positive features but would not necessarily result in crisis-prevention. 


\section{References}

Calvo, Guillermo A. (1989), "Incredible Reform," in G. A. Calvo, R. Findlay, P. Kouri, and J. B. de Macedo (editors) Debt, Stabilization and Development, New York: Basil Blackwell; reprinted in G. A. Calvo (editor) Money, Exchange Rates, and Output; Cambridge, MA: The MIT Press, 1996.

Calvo, Guillermo A. (1998), "Varieties of Capital-Market Crises," in G. Calvo and M. King (eds.) The Debt Burden and its Consequences for Monetary Policy, Macmillan.

Calvo, Guillermo A. (1999a) "Contagion in Emerging Markets: When Wall Street is a Carrier", (online paper) URL: http://www.bsos.umd.edu/econ/ciencrp8.pdf. Shorter version Publisher in the Proceedings from the International Economic Association Congress, vol. 3, Buenos Aires, Argentina 2002.

Calvo, Guillermo A. (1999b) “On Dollarization”, (online paper) URL: http://www.bsos.umd.edu/econ/ciecpn5.pdf. Published in Economics of Transition Journal, 2002.

Calvo, Guillermo. (2000) "Balance of Payments Crises in emerging Markets: Large Capital Inflows and Sovereign Governments", in Currency Crises Paul Krugman (editor), University of Chicago Press.

Calvo, Guillermo A. (2002), "Globalization Hazard and Delayed Reform in Emerging Markets", Economia 2 (2).

Calvo, Guillermo A., and Eduardo Borensztein (1989), "Perspectivas sobre el Problema de la Deuda," Trimestre Económico, special issue on Crecimiento, Equidad y Financiamiento Externo, 67, 1989, pp. 39-72.

Calvo, Guillermo A., and Fabrizio Coricelli (1992), "Stabilizing a Previously Centrally Planned Economy: Poland 1990," Economic Policy, April, pp. 176-208. Reprinted in G. A. Calvo (editor) Money, Exchange Rates, and Output; Cambridge, MA: The MIT Press, 1996.

Calvo, Guillermo A., Carmen Reinhart, and Leonardo Leiderman (1993) " Capital Inflows and Real Exchange Rate Appreciation in Latin America: The Role of External Factors”. IMF Staff Papers, Vol.40 (1): 108-151

Calvo, Guillermo A., and Enrique Mendoza. (2000) "Rational Contagion and the Globalization of Securities Markets", Journal of International Economics 51(1): 79113.

Calvo, Guillermo A. and Ernesto Talvi (2002), "Lula Effect? Look Again!”, Policy Note No. 12, CERES (Montevideo, Uruguay).

Calvo, Guillermo A., and Frederick Mishkin (2003), "The Mirage of Exchange Rate Regimes for Emerging Markets Countries”, Journal of Economic Perspectives 17(4). 
Calvo, Guillermo A., Alejandro Izquierdo, Ernesto Talvi (2003), "Sudden Stops, the Real Exchange Rate, and Fiscal Sustainability: Argentina's Lessons", National Bureau of Economic Research, NBER Working Paper No. 9828 (Cambridge, MA, USA).

Calvo, Guillermo A., Alejandro Izquierdo and Luis F. Mejia (2004), "On the empirics of Sudden Stops: The Relevance of Balance -Sheet Effects", NBER Working Paper No. 10520 (Cambridge, MA, USA).

Cowan, K., E. Hansen and L.O. Herrera (2004), "Currency Mismatches, Balance Sheet Effects and Hedging in Chilean Non-Financial Corporations", prepared for the conference "Vulnerabilidad Externa y Políticas de Prevención", Central Bank of Chile. Forthcoming in conference volume.

Eichegreen, Barry, and Ricardo Hausmann (2003), "The Road To Redemption" in Barry Eichengreen and Ricardo Hausmann (eds), Debt Denomination and Financial Instability in Emerging Market Economics, University of Chicago Press (forthcoming).

Furman, J, and J.E. Stiglitz (1998), "Economic Crises: Evidence and Insights from East Asia", Brookings Papers on Economic Activity, No. 2, Brookings Institution Press, pp. 1-114 (Washington, D.C.).

IADB (2005), Unlocking Credit, Economic and Social Progress Report, Inter-American Development Bank, (Washington, DC).

Kaminsky, Graciela and Carmen Reinhart (2001). "Bank Lending and Contagion: Evidence From the Asian Crisis" in Takatoshi Ito and Anne Krueger (eds), Regional and Global Capital Flows: Macroeconomic Causes and Consequences, University of Chicago Press for the NBER, 73-99.

Kaminsky, Graciela and Carmen Reinhart (2003). "The Center and the Periphery: The Globalization of Financial Shocks". NBER Working Paper 947, (Cambridge, Ma., USA).

Landerretche, Oscar, and Rodrigo Valdés (1997), "Indización: Historia Chilena y Experiencia Internacional”. Central Bank of Chile Working Paper 21 (Santiago, Chile).

Lora, Eduardo (2001), "Structural Reforms in Latin America: What Has Been Reformed and How to Measure It", RES Working Paper 466, Inter-American Development Bank, (Washington, DC).

Stiglitz, Joseph E. (2002), "Globalization and its Discontents", Norton \& Co. (New York, NY, USA).

Stiglitz, Joseph E. (2003), "El Rumbo de las Reformas: Hacia una Nueva Agenda para América Latina", Revista de la CEPAL No. 80 (Santiago, Chile). 